\title{
Pengelolaan Sudut Baca Kelas pada Jenjang Sekolah Dasar untuk Meningkatkan Minat Baca Peserta Didik
}

\author{
Indah Puspitasari*, Ali Imron, Juharyanto \\ Universitas Negeri Malang, Jl. Semarang No. 5 Malang, Jawa Timur, Indonesia \\ *Penulis korespondensi, Surel: indahpuspitas30@gmail.com
}

Paper received: 28-9-2021; revised: 12-10-2021; accepted: 19-10-2021

\begin{abstract}
The objectives of this research are: (1) describing reading corner planning at SDN 1 Lesanpuro Kedungkandang Malang City, (2) describing organizing reading corner at SDN 1 Lesanpuro Kedungkandang Kota Malang, (3) describing the implementation of reading corner in SDN 1 Lesanpuro Kedungkandang Malang City, (4) describes the supervision of reading corner at SDN 1 Lesanpuro Kedungkandang Malang, (5) describing the development of reading angles so as to increase the interest in reading learners, (6) describing the impact From the reading corner at SDN 1 Lesanpuro Malang City. The approach used is a qualitative approach, this type of research is descriptive research. The research plan used is a case study. Data analysis models used by researchers are models Milles and Huberman. Then check the validity of data using triangulation, member checking, overtime observation, improving persistence, and sufficiency of reference material. Based on the analysis of the data that has been done, the research conclusion is: (1) The planning is done by conducting meetings that include infrastructure and habituation programs, procurement of goods needed through School treasurer, and the arrangement of infrastructure to the designated place; (2) Organizing is done by delegating duties to members who have already written on the organizational structure; (3) The implementation of the reading corner includes a silent read, retelling the summary of the story on the read book, and writing good; (4) Some of the things that become evaluation of reading corner activity are less reading material, reading interest of students, maximising time to visit reading corner, order students when in reading corner; (5) The strategy is done by establishing cooperation with parents and the public library of Malang City; (6) The impact of reading angle programs is to develop 4 aspects of language that students have, i.e. reading, writing, speaking, and listening.
\end{abstract}

Keywords: management; reading angles; reading interests

\begin{abstract}
Abstrak
Tujuan penelitian ini adalah: (1) mendeskripsikan perencanaan sudut baca di SDN 1 Lesanpuro Kedungkandang Kota Malang, (2) mendeskripsikan pengorganisasian sudut baca di SDN 1 Lesanpuro Kedungkandang Kota Malang, (3) mendeskripsikan pelaksanaan sudut baca di SDN 1 Lesanpuro Kedungkandang Kota Malang, (4) mendeskripsikan pengawasan sudut baca di SDN 1 Lesanpuro Kedungkandang Kota Malang, (5) mendeskripsikan pengembangan sudut baca sehingga dapat meningkatkan minat baca peserta didik, (6) mendeskripsikan dampak dari adanya sudut baca di SDN 1 Lesanpuro Kota Malang. Pendekatan yang digunakan adalah pendekatan kualitatif, jenis penelitian ini adalah penelitian deskriptif. Sedangkan rancangan penelitian yang digunakan adalah studi kasus. Model analisis data yang digunakan peneliti adalah model Milles dan Huberman. Kemudian melakukan pengecekan keabsahan data dengan menggunakan triangulasi, pengecekan anggota, perpanjangan waktu pengamatan, meningkatkan ketekunan, dan kecukupan bahan referensi. Berdasarkan analisis data yang sudah dilakukan, simpulan penelitian ini adalah: (1) perencanaan yang dilakukan adalah dengan melaksanakan rapat yang meliputi sarana prasarana dan program pembiasaan, pengadaan barang-barang yang dibutuhkan melalui bendahara sekolah, dan penataan prasarana ke tempat yang sudah ditentukan; (2) pengorganisasian dilakukan dengan mendelegasikan tugas kepada anggota yang sudah tertulis pada struktur organisasi; (3) pelaksanaan sudut baca meliputi kegiatan membaca senyap, menceritakan kembali ringkasan cerita pada buku yang sudah dibaca, dan menulis kebaikan; (4) Beberapa hal yang menjadi bahan evaluasi program sudut baca yaitu bahan bacaan yang kurang, minat baca siswa, memaksimalkan waktu untuk mengunjungi sudut baca, ketertiban siswa saat berada di sudut baca; (5) Strategi dilakukan dengan
\end{abstract}


menjalin kerjasama dengan orang tua siswa dan Perpustakaan Umum Kota Malang; (6) Dampak program sudut baca adalah mengembangkan 4 aspek bahasa yang dimiliki siswa yaitu membaca, menulis, berbicara, dan mendengarkan.

Kata kunci: pengelolaan; sudut baca; minat baca

\section{Pendahuluan}

Pelaksanaan program sudut baca di SDN Lesanpuro 1 Kota Malang dimulai sejak tahun 2013. Pengadaan sudut baca dilatarbelakangi oleh keinginan kepala sekolah untuk menumbuhkan budaya baca bagi peserta didik. Selain itu, sekolah berupaya agar peserta didik lebih dekat dengan bahan bacaan sehingga berpengaruh meningkatkan wawasan yang dimiliki. Perlu diketahui, manfaat membaca sangat banyak terutama untuk peserta didik. Bahkan membaca memiliki peran penting bagi pembentukan karakter peserta didik (Juharyanto, Yusuf Sobri, \& Nurabadi, 2019). Tujuan utama dalam membaca adalah untuk mencari serta memperoleh informasi, mencakup isi, memahami makna bacaan (Tarigan, 2008). Tujuan membaca tersebut berguna untuk meningkatkan prestasi dalam bidang akademik karena membaca merupakan salah satu cara untuk dapat memahami materi atau bahan pelajaran yang diberikan oleh guru (Kurniawan, Sriasih, \& Nurjaya, 2017; Triatma, 2016). Langkah awal dalam melaksanakan program tersebut adalah mengadakan bahan bacaan. Bahan bacaan atau buku diperoleh dari Dinas Pendidikan Kota Malang sebanyak 1000 buku. Program sudut baca tidak hanya melibatkan seluruh elemen sekolah saja, akan tetapi orang tua peserta didik juga turut berpartisipasi dalam mensukseskan keberhasilan program tersebut.

Pelaksanaan sudut baca di SDN Lesanpuro 1 Kota Malang dapat dikategorikan berhasil, minat peserta didik dalam membaca juga meningkat. Berdasarkan pengamatan yang dilakukan oleh peneliti, pada saat jam istirahat sedang berlangsung terdapat siswa yang sedang membaca di sudut baca kelompok. Karakteristik penerapan sudut baca di sekolah ini adalah keberlanjutan program berupa jadwal kegiatan untuk mendukung gerakan literasi. Kegiatan yang dilakukan peserta didik adalah membaca cerita setelah upacara bendera pada hari senin, menulis hal kebaikan yang pernah dilakukan, membaca senyap dalam kelas, dan membiasakan satu hari berbahasa jawa pada hari jumat. Strategi tersebut dapat meningkatkan kemampuan menulis dalam menghasilkan karya seperti puisi, cerita, dan lain-lain. Selain itu, dapat meningkatkan kemampuan berbahasa yang dimiliki peserta didik.

Kegiatan sudut baca dilatarbelakangi oleh minat baca masyarakat Indonesia yang berkategori rendah. Data UNESCO menyebutkan bahwa Indonesia berada pada urutan kedua dari bawah soal literasi dunia. Minat baca masyarakat Indonesia hanya $0,001 \%$. Artinya, dari 1000 orang Indonesia, hanya 1 orang yang rajin membaca (Hamdani, 28 Januari 2019). Data Perpustakaan Nasional pada tahun 2017 menyatakan bahwa frekuensi membaca masyarakat Indonesia rata-rata hanya tiga sampai empat kali setiap minggunya. Sedangkan rata-rata jumlah buku yang dibaca adalah lima sampai sembilan buku per tahun (Pratiwi, 27 Maret 2018).

Salah satu upaya yang dapat dilakukan adalah dengan mengelola sarana perpustakaan. Perpustakaan sebagai sumber belajar akan memiliki kinerja yang baik apabila dikelola atau dimanage dengan baik (Zulkarnain, 2016). Seiring dengan tuntutan perkembangan ilmu pengetahuan dan teknologi, perpustakaan tidak hanya terletak pada suatu ruang saja, akan 
tetapi juga terdapat di setiap sudut kelas ataupun sudut sekolah yang biasa disebut dengan sudut baca (Faizah, 2016). Sudut baca merupakan perpanjangan fungsi dari perpustakaan. Sudut baca kelas adalah sebuah tempat di kelas yang dilengkapi dengan koleksi buku dan ditata secara menarik untuk meningkatkan minat baca peserta didik (Hartyatni, 2018). Sudut baca merupakan salah satu upaya dari Gerakan Literasi Sekolah (GLS). GLS merupakan salah satu kegiatan yang mewakili gerakan penumbuhan budi pekerti sebagaimana yang terdapat dalam Permendikbud Nomor 23 Tahun 2015.

Penelitian dengan judul Pengelolaan Sudut Baca pada Jenjang Sekolah Dasar untuk Meningkatkan Minat Baca Peserta Didik (Studi Kasus di SDN Lesanpuro 1 Kota Malang) mempunyai keunikan tersendiri yaitu mencakup keterampilan berbahasa. Tidak hanya minat baca siswa saja yang ditingkatkan, namun keterampilan berbahasa yang meliputi membaca, berbicara, menulis, dan mendengarkan juga diasah sehingga kemampuan tersebut dapat berkembang. Misalnya setelah kegiatan membaca senyap, guru menginstruksikan untuk menceritakan kembali sinopsis atau ringkasan buku yang telah dibaca. Kegiatan tersebut melatih kemampuan membaca dengan memahami isi bacaan dan melatih kemampuan berbicara di depan banyak orang.

\section{Metode}

Jenis penelitian ini adalah penelitian deskriptif yang bertujuan menggambarkan dan mendeskripsikan karakteristik suatu fenomena. Rancangan penelitian yang digunakan adalah studi kasus. Alasan peneliti memilih studi kasus karena ingin mengetahui dan menemukan fenomena secara rinci mengenai pengelolaan sudut baca sekolah yang ada di SDN Lesanpuro 1 Kota Malang kemudian menganalisis dan mengembangkan kerangka teorinya. Penelitian ini menggunakan teknik observasi, wawancara, dan dokumentasi. Teknik observasi yaitu dengan melakukan kunjungan ke SD Negeri 1 Lesanpuro Kota Malang untuk mengamati lingkungan fisik, mengamati aktivitas dan perilaku subjek penelitian yaitu peserta didik. Teknik wawancara dilakukan secara langsung melalui pertanyaan yang diajukan secara lisan kepada informan yang meliputi kepala sekolah, guru, dan peserta didik. Teknik dokumentasi dilakukan peneliti karena dokumen berfungsi sebagai bukti yang kuat dalam penelitian sehingga peneliti dapat mengetahui kelengkapan program yang ada di sekolah tersebut. Peneliti mengumpulkan data pendukung berupa dokumen yang dimiliki oleh sekolah, foto kegiatan sekolah yang berkaitan dengan program sudut baca, serta foto sarana dan prasarana sudut baca. Kemudian dilakukan analisis data menggunakan model Miles and Huberman dengan tahap reduction, data display, dan conclusion drawing/verification. Selanjutnya melakukan pengecekan keabsahan data dengan triangulasi sumber dan triangulasi teknik. Triangulasi sumber atau member check dilakukan dengan membandingkan atau mengecek kembali informasi yang diperoleh dari informan yang berbeda. Triangulasi teknik dilakukan dengan membandingkan transkrip wawancara dengan catatan lapangan yang telah dibuat, apabila keduanya sesuai maka dapat dikatakan data tersebut valid. 


\section{Hasil dan Pembahasan}

\subsection{Hasil}

\subsubsection{Perencanaan Kegiatan Sudut Baca}

Perencanaan kegiatan sudut baca di SDN Lesanpuro 1 Kota Malang dimulai dengan mengadakan rapat dengan melibatkan kepala sekolah dan guru yang membahas tentang persiapan pelaksanaan sudut baca. Kemudian dilakukan pengadaan barang-arang yang dibutuhkan. Penempatan sarana dan prasarana sudut baca juga perlu ditata dengan rapi agar peserta didik merasa tertarik. Hal-hal yang perlu diperhatikan dalam menentukan letak sudut baca adalah: 1) letak yang strategis, dapat mempermudah siswa untuk menjangkau bahan bacaan yang diinginkan; 2) pencahayaannya baik, berguna agar siswa dapat membaca buku dengan jelas di tempat tersebut; 3) aman dari gangguan nyamuk dan hewan pengerat sehingga siswa merasa nyaman serta bahan bacaan terhindar dari hewan pengerat.

Selain sarana juga diperlukan prasarana untuk menunjang pelaksanaan kegiatan sudut baca. Prasarana tersebut antara lain adalah rak buku, bahan bacaan dan administrasi. Sedangkan administrasi yang dimaksud adalah daftar pengunjung dan daftar peminjam. Daftar pengunjung dan daftar peminjam berfungsi untuk mengetahui siswa yang sering ataupun yang jarang berkunjung maupun meminjam buku di sudut baca. Tindak lanjut dari daftar tersebut adalah reward bagi siswa yang sering berkunjung.

Tahap awal untuk memperkenalkan budaya membaca adalah dengan menyisipkan pada pembelajaran tertentu. Kegiatan pembiasaan yang diterapkan oleh kepala sekolah SDN Lesanpuro 1 Kota Malang adalah kegiatan membaca senyap. Kegiatan tersebut dilaksanakan setiap hari kamis pagi setelah bel masuk berbunyi. Durasi kegiatan tersebut selama 20 menit. Biasanya dilanjutkan dengan menceritakan kembali isi buku yang telah dibaca di depan kelas. Setiap hari rabu, siswa menulis kebaikan yang dilakukan selama satu minggu. Hasil dari kegiatan tersebut dihimpun menjadi buku yang diletakkan di sudut baca.

\subsubsection{Pengorganisasian Kegiatan Sudut Baca}

Tahap ini adalah proses pendelegasian tugas dan wewenang kepada anggota. Wujud dari pengorganisasian adalah adanya struktur organisasi yang jelas agar anggota dapat bertanggung jawab atas tugas yang telah diberikan. Struktur organisasi kegiatan sudut baca dibagi menjadi 2 yaitu struktur organisasi sudut baca kelas dan struktur organisasi sudut baca secara keseluruhan saat ajang Green School Festival (GSF). Struktur organisasi sudut baca kelas mengacu pada struktur organisasi kelas, sehingga yang bertanggung jawab adalah pengurus kelas meliputi ketua, wakil ketua, dan sekretaris. Struktur organisasi sudut baca secara keseluruhan saat ajang Green School Festival (GSF) terdiri dari kepala sekolah, pustakawan, guru, tim isu literasi, dan siswa.

\subsubsection{Pelaksanaan Kegiatan Sudut Baca}

Langkah awal yang dilakukan oleh pihak sekolah untuk membiasakan siswa terhadap budaya membaca adalah dengan menyisipkan pada pembelajaran. Kegiatan lanjutan yang dilakukan adalah membaca senyap. Kegiatan membaca senyap adalah kegiatan membaca dalam hati yang dilakukan sebagai upaya untuk membiasakan siswa terhadap kegiatan 
membaca. Kegiatan tersebut dilaksanakan setiap hari kamis pagi selama kurang lebih 15 hingga 30 menit. Banyaknya siswa yang ada di SDN Lesanpuro 1 Kota Malang membuat tahap ini mengalami permasalahan. Permasalahan yang dialami adalah kurang tertibnya siswa saat ada di sudut baca. Seringkali siswa saat memilih buku terlalu lama sehingga menciptakan antrian dengan siswa lain yang ingin membaca. Kemudian saat mengembalikan buku terdapat beberapa siswa yang kurang rapi saat meletakkan buku di rak. Permasalahan lainnya adalah bahan bacaan yang kurang.

Pihak sekolah menerapkan dua solusi untuk mengatasi permasalahan tersebut. Pertama, memindahkan sudut baca kelompok. Letak sudut baca yang dipindah dari kelas satu ke kelas lainnya membuat siswa bisa membaca buku yang bervariasi sehingga tidak merasa bosan. Kedua, menjalin kerjasama dengan Perpustakaan Umum Kota Malang. Bentuk kerjasama yang dilakukan adalah dengan meminjamkan sejumlah buku setiap 2 bulan sekali. Setiap kali kunjung dibatasi sebanyak 90 anak.

\subsubsection{Pengawasan Kegiatan Sudut Baca}

Pengawasan merupakan suatu tahap untuk menilai keberhasilan pelaksanaan kegiatan. Fungsi pengawasan adalah mengetahui kekurangan-kekurangan selama kegiatan tersebut diterapkan untuk kemudian memperbaikinya agar dapat berlangsung terus menerus dan berkembang menjadi lebih baik. Beberapa hal yang menjadi bahan evaluasi kegiatan sudut baca di SDN Lesanpuro 1 Kota Malang adalah yaitu bahan bacaan yang kurang, minat baca siswa, memaksimalkan waktu untuk mengunjungi sudut baca, ketertiban siswa saat berada di sudut baca.

Suatu kegiatan dikatakan berhasil dilihat dari dampak yang dihasilkan dari implementasi kegiatan tersebut. Indikator keberhasilan sudut baca di SDN Lesanpuro 1 Kota malang dapat dilihat dari kemampuan berbahasa siswa. Hal tersebut dapat dibuktikan dengan rata-rata siswa kelas I sudah lancar membaca. Kegiatan membaca secara tidak langsung dapat mempengaruhi kemampuan siswa untuk berbicara dengan menggunakan tata bahasa yang baik dan sopan, dapat dibuktikan dengan siswa yang mengikuti lomba pidato hingga ke tingkat kota.

\subsubsection{Strategi untuk Mengembangkan Kegiatan Sudut Baca}

Strategi digunakan untuk mengembangkan kegiatan kearah yang lebih baik. Menjalin kerjasama dirasa sebagai strategi yang tepat untuk meningkatkan kualitas suatu kegiatan. Sekolah menjalin kerjasama dengan wali murid dan Perpustakaan Umum Kota Malang. Kerjasama yang dijalin dengan wali murid dalam bentuk materi (bahan bacaan) serta tenaga. Sedangkan kerjasama dengan Perpustakaan Umum Kota Malang adalah dengan mendatangi sekolah menggunakan perpustakaan keliling, kemudian meminjamkan sejumlah buku dalam kurun waktu tertentu.

\subsubsection{Dampak Kegiatan Sudut Baca}

Dampak kegiatan sudut baca adalah mengembangkan 4 aspek bahasa yang dimiliki siswa, antara lain membaca, menulis, berbicara, dan mendengarkan. Sekolah menerapkan beberapa kegiatan untuk mendukung siswa mengembangkan aspek berbahasa. Pertama, aspek membaca dengan menerapkan kegiatan membaca senyap setiap hari kamis pagi. Kedua, 
aspek menulis dengan menerapkan kegiatan menulis kebaikan yang dilaksanakan setiap hari rabu pagi sebelum jam pelajaran jam pertama dimulai. Ketiga, aspek berbicara dengan menerapkan kegiatan bercerita di depan kelas setelah membaca senyap. Keempat, aspek mendengarkan. Siswa lain yang mendengarkan temannya bercerita secara tidak langsung akan meningkatkan kemampuan untuk mencerna isi cerita yang disampaikan.

\subsection{Pembahasan}

\subsubsection{Perencanaan Kegiatan Sudut Baca}

Tahap perencanaan adalah tahap penentuan strategi yang akan diterapkan pada tahap pelaksanaan Kegiatan. Strategi yang diambil untuk pengelolaan sudut baca dibahas melalui rapat oleh kepala sekolah dan guru. Rapat tersebut membahas tentang persiapan pelaksanaan sudut baca diantaranya adalah sarana prasarana serta kegiatan pembiasaan. Hal tersebut sesuai dengan pendapat Benty dan Gunawan (2017) yang menyatakan bahwa perencanaan adalah proses mendefinisikan tujuan organisasi, membuat strategi untuk mencapai tujuan, dan mengembangkan rencana aktivitas kerja suatu organisasi. Strategi penting untuk dirumuskan agar mengetahui langkah yang akan diambil sehingga dapat mencapai tujuan yang telah ditetapkan.

Setelah melaksanakan rapat tahap selanjutnya adalah mengadakan sarana dan prasarana yang dibutuhkan tentunya dengan melalui bendahara karena dana yang digunakan adalah dana BOS. Tahap selanjutnya adalah pendistribusian prasarana ke sudut baca kelas maupun sudut baca kelompok. Prasarana yang direncanakan meliputi rak buku, bahan bacaan, dan keperluan administrasi. Pembuatan sudut baca sendiri tidak sekedar pengumpulan koleksi saja. Pengumpulan koleksi saja belum cukup untuk menarik siswa mengunjungi dan beraktivitas di dalamnya (Hari Santoso, 2007; Widiasa, 2007). Sebuah perpustakaan kecil harus didekorasi dengan cantik sehingga siswa betah berlama-lama di dalamnya (Lestari, 2017). Sedangkan sarana yang dipersiapkan tentunya adalah tempat untuk meletakkan sudut baca. Kegiatan pembiasaan yang diterapkan adalah membaca senyap. Kegiatan membaca senyap dilakukan rutin sekali dalam seminggu pada hari kamis. Kegiatan tersebut berlangsung selama 15 menit sebelum mata pelajaran pertama dimulai. Hal tersebut sesuai dengan yang dilakukan di SD Negeri Pamongan 2 yaitu pada tahap pembiasaan dilakukan melalui kegiatan membaca selama 15 menit sebelum kegiatan pembelajaran dimulai (Ramandanu, 2019). Kemudian guru menginstruksikan untuk menceritakan kembali isi buku yang telah dibaca di depan kelas. Kegiatan lainnya adalah menulis kebaikan yang dilakukan selama satu minggu sebelumnya. Kegiatan tersebut dilakukan setiap hari rabu.

\subsubsection{Pengorganisasian Kegiatan Sudut Baca}

Wujud dari tahap pengorganisasian adalah adanya struktur organisasi. Struktur organisasi sudut baca di SDN Lesanpuro 1 Kota Malang terdiri dari struktur organisasi sudut baca kelas dan sudut baca secara keseluruhan saat ajang GSF. Struktur organisasi sudut baca pada ajang GSF sama dengan tugas tim literasi sekolah. Dalam kedudukannya sebagai sebuah tim ada beberapa tugas pokok dan fungsi (tupoksi) TLS untuk menumbuhkembangkan GLS di tiap sekolah. Adapun tugas-tugas minimal TLS berdasarkan tahap-tahapnya adalah merencanakan, melaksanakan, melaporkan, dan melakukan asesmen serta mengevaluasi pelaksanaan GLS (Kementerian Pendidikan dan Kebudayaan, 2016). Temuan penelitian 
mengenai kegiatan pendelegasian tugas tersebut sesuai dengan pendapat Fattah (2013) yang menyatakan bahwa pengorganisasian sebagai proses membagi kerja ke dalam tugas-tugas yang lebih kecil, membebankan tugas-tugas tersebut kepada orang yang sesuai dengan kemampuannya, dan mengalokasikan sumber daya, serta mengkoordinasikannya dalam rangka efektivitas pencapaian tujuan organisasi. Pengorganisasian berkaitan dengan kegiatan pemberian tugas kepada anggota (Nugrohoadhi, 2015; Saefudin, 2017). Tugas dari pengurus kelas adalah menata buku yang ada di sudut baca kelas masing-masing dan mengganti daftar peminjam jika sudah habis. Temuan tersebut sesuai dengan tahap pengorganisasian sudut baca kelas di SMP Negeri 2 Balongbendo Sidoarjo yang dikelola oleh siswa kelas sendiri, sehingga kepengurusan perpustakaan kelas sepenuhnya tanggung jawab siswa (Anggraeni, 2016). Tugas tim isu literasi sama dengan tugas pengurus kelas, hanya saja lingkupnya lebih besar. Tim isu literasi bertanggungjawab terhadap seluruh sudut baca yang ada di sekolah, mencakup sudut baca kelas, sudut baca kelompok, dan perpustakaan.

\subsubsection{Pelaksanaan Kegiatan Sudut Baca}

Pelaksanaan kegiatan sudut baca diawali dengan kegiatan membaca senyap, dilakukan setiap hari kamis, 15 menit sebelum mata pelajaran jam pertama dimulai. Kegiatan tersebut sama dengan program jam baca yang diterapkan di SMP Negeri 1 Puri. Siswa akan dibimbing oleh guru. Selain itu,program ini tidak terikat pada nilai sehingga siswa tidak merasa terbebani (Arisma, 2012). Guru mengarahkan peserta didik untuk membawa buku dari rumah, jika ada yang tidak membawa bisa meminjam di sudut baca kelas atau sudut baca kelompok. Setelah membaca, siswa diinstruksikan untuk menceritakan kembali ringkasan dari buku yang sudah dibaca. Kegiatan tersebut hampir sama dengan yang dilakukan di SMP Negeri 2 Balongbendo Sidoarjo dimana siswa akan melakukan resume bacaan yang sudah dibaca (Anggraeni, 2016). Tahap pelaksanaan kegiatan sudut baca di SDN Lesanpuro 1 Kota Malang tidak terlepas dari hal-hal yang dapat menghambat keberhasilan kegiatan. Hambatan tersebut berasal dari faktor prasarana yang dimiliki, yaitu keterbatasan bahan bacaan.

Pihak sekolah berusaha mengatasi permasalahan tersebut melalui dua cara yaitu memindahkan letak sudut baca kelompok dan menjalin kerjasama dengan Perpustakaan Umum Kota Malang. Sudut baca kelompok ditukar satu dengan lainnya sehingga peserta didik dapat membaca buku lain yang belum pernah dibaca. Sedangkan kerjasama yang dilakukan adalah dengan meminjamkan buku kepada sekolah untuk kemudian didistribusikan ke sudut baca kelompok yang tersebar di tiga titik bagian sekolah. Sudut baca kelompok yang ada di SDN Lesanpuro 1 Kota Malang berbentuk rak buku yang diberi roda. Sudut baca tersebut adalah salah satu jenis sudut baca yang diklasifikasikan oleh Christina (2013). Sudut baca tersebut dinamakan sudut baca beroda.

\subsubsection{Pengawasan Kegiatan Sudut Baca}

Penjelasan yang disampaikan Widiasa (2007), bahwa perpustakaan sekolah kebanyakan belum memiliki sumber daya manusia sebagai pengelola perpustakaan secara baik dan memadai. Pengawasan sudut baca yang ada di SDN Lesanpuro 1 Kota Malang dilakukan oleh kepala sekolah dan guru secara rutin agar dapat mengatasi permasalahan-permasalahan yang terjadi saat mengelola kegiatan sudut baca. Temuan tersebut sesuai dengan pendapat Benty dan Gunawan (2017) yang menyatakan bahwa pengawasan adalah proses menetapkan ukuran kinerja suatu organisasi dan pengambilan tindakan yang diharapkan dapat mendukung hasil 
yang akan dicapai. Adapun evaluasi GLS dilaksanakan setiap semester. Hasil evaluasi akan menentukan apakah sebuah sekolah dapat beralih jenjang dari tahap pembiasaan ke tahap pengembangan atau dari tahap pengembangan ke tahap pembelajaran. Koordinasi dengan pihak internal dapat dilakukan setiap minggu atau sesuai dengan situasi dan kondisi sekolah (Kementerian Pendidikan dan Kebudayaan, 2016).

\subsubsection{Strategi untuk Mengembangkan Kegiatan Sudut Baca}

Strategi yang dilakukan untuk mengembangkan sudut baca adalah menjalin kerjasama. SDN Lesanpuro 1 Kota Malang menjalin kerjasama dengan orang tua siswa dan Perpustakaan Umum Kota Malang. Hal tersebut sesuai dengan pendapat Nugroho (2016) mengenai peningkatan kualitas sarana dengan berkolaborasi bersama perpustakaan sampai menjalin kerjasama dengan pihak luar sekolah untuk menambah koleksi bacaan. Strategi yang diterapkan tersebut melibatkan pemerintah khususnya dalam bidang perpustakaan. Hal tersebut sesuai dengan pendapat Kasiyun (2015) yang mengemukakan bahwa strategi untuk meningkatkan minat baca adalah dengan memperbaiki sistem pendidikan, fasilitas dan karakteristik pelayanan perpustakaan, membuat kebijakan anggaran belanja yang harus dikeluarkan untuk perpustakaan (sebesar 2-3\% setiap tahun). Pengembangan sarana literasi membutuhkan sumber daya yang memadai. Partisipasi komite sekolah, orang tua, alumni, dan dunia bisnis dan industri dapat membantu memelihara dan mengembangkan sarana sekolah agar capaian literasi peserta didik dapat terus ditingkatkan (Faizah, 2016).

\subsubsection{Dampak Kegiatan Sudut Baca}

Dampak kegiatan sudut baca tentunya dapat meningkatkan minat baca siswa. Selain itu juga dapat mengembangkan 4 aspek bahasa yang dimiliki siswa, antara lain membaca, menulis, berbicara, dan mendengarkan. Hal tersebut sesuai dengan pendapat Faizah (2016) bahwa kegiatan literasi pada tahap pembelajaran meningkatkan kemampuan berbahasa reseptif (membaca dan menyimak) dan aktif (berbicara dan menulis) yang sudah dilakukan pada tahap pengembangan. SDN Lesanpuro 1 Kota Malang menerapkan kegiatan yang dapat mengembangkan aspek berbahasa yang dimiliki siswa. Dampak yang terjadi dari pengelolaan sudut baca tersebut juga disampaikan oleh Christina(2013) yaitu meningkatnya kemampuan membaca dan berkomunikasi peserta didik dan guru. Membaca dapat menambah wawasan dan pengetahuan. Selain itu juga dapat menambah kosakata yang dimiliki sehingga berdampak pada kemampuan berkomunikasi bagi pembaca. SDN Lesanpuro 1 Kota Malang menerapkan kegiatan membaca senyap. Dampak positifnya terhadap sikap membaca yang positif baru bisa dirasakan bila dilakukan secara berkala dan konsisten selama minimal tiga bulan. Setelah tahun pertama berlalu, Membaca dalam hati mulai menunjukkan pengaruhnya terhadap kemampuan membaca, menulis, kosakata, tata bahasa dan ejaan (Kementerian Pendidikan dan Kebudayaan, 2016).

\section{Simpulan}

Perencanaan kegiatan sudut baca diawali dengan mendiskusikan persiapan pelaksanaan sudut baca dengan melibatkan kepala sekolah dan guru. Rapat tersebut membahas tentang berbagai persiapan pelaksanaan sudut baca yang meliputi sarana prasarana dan program pembiasaan. Kemudian dilakukan pengadaan barang-barang yang dibutuhkan melalui bendahara sekolah. Penempatan sarana dan prasarana sudut baca juga perlu ditata dengan rapi agar peserta didik merasa tertarik. Tahapselanjutnya yaitu tahap 
pengorganisasian yang dilakukan dengan mendelegasikan tugas kepada anggota yang memiliki kemampuan dalam bidang yang berkaitan. Struktur organisasi program sudut baca yang ada di SDN Lesanpuro 1 Kota Malang dibagi menjadi 2 yaitu struktur organisasi sudut baca kelas dan struktur organisasi sudut baca secara keseluruhan saat ajang Green School Festival (GSF). Pelaksanaan kegiatan sudut baca dimulai dengan membiasakan budaya membaca kepada siswa melalui pembelajaran di kelas.Tindakan lanjutan yang diterapkan adalah membaca senyap, dilanjutkan dengan menceritakan kembali ringkasan cerita pada buku yang sudah dibaca, menulis kebaikan. Pengawasan kegiatan sudut baca rutin dilaksanakan oleh kepala sekolah dan guru agar dapat mengetahui letak kekurangan program sudut baca sehingga dapat dilakukan perbaikan. Pengembangan sudut baca dilakukan dengan menjalin kerjasama dengan orang tua siswa dan Perpustakaan Umum Kota Malang. Dampak program sudut baca adalah mengembangkan 4 aspek bahasa yang dimiliki siswa yaitu membaca, menulis, berbicara, dan mendengarkan.

\section{Daftar Rujukan}

Anggraeni, I. (2016). Strategi Kepala Sekolah untuk Meningkatkan Gemar Membaca Siswa di SMP Negeri 2 Balongbendo Sidoarjo. Inspirasi Manajemen Pendidikan, 4(1).

Arisma, O. (2012). Peningkatan Minat dan Kemampuan Membaca melalui Penerapan Program Jam Baca Sekolah di Kelas VII SMP Negeri 1 Puri,

Benty \& Gunawan. (2017). Manajemen Pendidikan: Suatu Pengantar Praktik. Bandung: Alfabeta.

Christina, P. (2013). Pemanfaatan Sudut Baca Untuk Meningkatkan Kemampuan Memahami Isi Bacaan Pada Siswa Kelas IV di SDN Sitimerto Kabupaten Kediri,

Faizah, dkk. (2016). Panduan Gerakan Literasi Sekolah di Sekolah Dasar. Jakarta: Direktorat Pembinaan Sekolah Dasar Kementerian Pendidikan dan Kebudayaan.

Fattah, N. (2013). Landasan Manajemen Pendidikan. Bandung: Remaja Rosdakarya.

Hamdani. (2019). Laporan World's Most Literate Nations Indonesia Darurat Membaca, (Online), (https://www.kompasiana.com/cangkoiburong/5c4ec840c112fe193a7a94a5/laporan-most-

literred-nation-in-the-world-indonesia-darurat-literasi-membaca?page=all), diakses pada 24 Juni 2019.

Hartyatni, M. S. (2018). Membangun Budaya Baca Melalui Pengelolaan Media Sudut Baca Kelas Dengan "12345". Jurnal Pemikiran dan Pengembangan Sekolah Dasar (JP2SD), 6(1), 1-11.

Sobri, A. Y., \& Nurabadi, A. (2018, December). The Principal Leadership in Strengthening Elementary School Education Character. In International Conference on Education and Technology (ICET 2018) (pp. 248254). Atlantis Press.

Kasiyun, S. (2015). Upaya meningkatkan minat baca sebagai sarana untuk mencerdaskan bangsa. Jurnal Pena Indonesia, 1(1), 79-95.

Kementerian Pendidikan dan Kebudayaan. (2016). Manual Pendukung Pelaksanaan Gerakan Literasi Sekolah untuk Jenjang Sekolah Menengah Pertama, (Online) (http://118.98.227.114/glnsite/wpcontent/uploads/2017/09/Manual-Pendukung-Pelaksanaan-Gerakan-Literasi-Sekolah.pdf), diakses pada 20 Agustus 2019

Kurniawan, K. I., Sriasih, S. A. P., \& Nurjaya, I. G. (2017). Implementasi Program Gerakan Literasi Sekolah (GLS) di SMA Negeri 1 Singaraja. Jurnal Pendidikan Bahasa dan Sastra Indonesia Undiksha, 7(2).

Lestari, S. (2017). Upaya Mensukseskan Gerakan Literasi Sekolah Melalui Pengelolaan Sudut Baca Kelas, (Online) (https://arsipdanperpustakaan.jogjakota.go.id), diakses pada 20 Agustus 2019.

Nugroho, dkk. (2016). Implementasi Gemar Membaca Melalui Program Pojok

Nugrohoadhi, A. (2015). Pengorganisasian dokumen dalam kegiatan kepustakawanan. Khizanah Al-Hikmah: Jurnal Ilmu Perpustakaan, Informasi, Dan Kearsipan, 3(1), 1-10.

Nugroho, A. H., Puspitasari, R., \& Puspitasari, E. (2016). Implementasi gemar membaca melalui program pojok baca dalam mata pelajaran IPS pada siswa kelas VIII di SMPN 2 Sumber. Jurnal Edueksos, 5(2), 187-206. 
Jurnal Pembelajaran, Bimbingan, dan Pengelolaan Pendidikan, 1(10), 2021, 815-824

Pratiwi, P. (2018). Minat Baca Masyarakat Indonesia Masih Rendah, (Online), (https://www.cnnindonesia.com/gaya-hidup/20180326160959-282-285982/minat-bacamasyarakat-indonesia-masih-rendah), diakses pada 24 Juni 2019.

Ramandanu, F. (2019). Gerakan literasi sekolah (GLS) melalui pemanfaatan sudut baca kelas sebagai sarana alternatif penumbuhan minat baca siswa. Mimbar Ilmu, 24(1), 10-19.

Saefrudin, S. (2017). Pengorganisasian Dalam Manajemen. Al-Hikmah: Jurnal Kependidikan Dan Syariah, 5(2), 56-67.

Santoso, H. (2007). Promosi sebagai media pemberdayaan perpustakaan sekolah. Jurnal Perpustakaan Sekolah, $1(1), 1-8$.

Widiasa, I. K. (2007). Manajemen Perpustakaan Sekolah. Jurnal Perpustakaan Sekolah, Tahun, 1, 1-14.

Zulkarnain, W. (2016). Layanan Khusus Peserta Didik sebagai Penguat Manajemen Pendidikan. https://ap.fip.um.ac.id/wp-content/uploads/.../4-Wildan-Zulkarnain.pdf,2016. 